\title{
Social Media Use Purposes of Children and The Impact of Their Self-Directed Learning with Technology on Health Literacy
}

\author{
Dijle AYAR ${ }^{1}$, (id İlknur BEKTAŞ², (iD) Aslı AKDENIZ KUDUBEŞ ${ }^{3}$, (iD) Murat BEKTAŞ ${ }^{4}$
}

'Phd, Assoc Prof, Dokuz Eylul University Faculty of Nursing, Pediatric Nursing Department, Izmir, Turkey. 2Phd, Lecturer, Dokuz Eylul University Faculty of Nursing, Pediatric Nursing Department, Izmir, Turkey.

${ }^{3}$ Phd, Assist, Prof, Bilecik Şeyh Edebali University Faculty of Health Sciences, Pediatric Nursing Department, Bilecik, Turkey.

${ }^{4}$ Phd, Prof Dr Dokuz Eylul University Faculty of Nursing, Pediatric Nursing Department, Izmir, Turkey.

\begin{abstract}
Background: Health literacy is described as a means to obtain new information and reach more positive attitudes, more competence, positive health behaviors and better health outcomes. Social media use and self-directed learning with technology affecting health literacy of children. Objectives: This study is to examine the effect of social media and their self-directed learning with technology on health literacy. Methods: The study was conducted with a total of 507 students from two secondary schools located in Turkey's Aegean region. Descriptive Information Form", "Social Media Purpose Use Scale", "Self-Directed Learning with Technology Scale" and "Health Literacy Scale for School-Aged Children" were used as data collection tools. Results: Result of the regression analysis showed, there was a positive moderate significant correlation between the mean total scores of the purpose of social media use $(\beta=.60, p<.001)$ and health literacy there was a positive moderate significant correlation between self-directed learning with technology $(\beta=.58, \mathrm{p}<.001)$ and health literacy. The health literacy of the students was mostly affected from the mean total scores of the purpose of social media use and the self-directed learning with technology, respectively. It was found that $46 \%(\mathrm{~F}=215.872, \mathrm{p}<.001)$ of the factors affecting the health literacy in the overall model could be accounted by the purpose of social media use and self-directed learning with technology. Conclusion: It is reported that there is a positive significant correlation between health literacy of the children and the purposes of social media use and self-directed learning with technology.

Key Words: Social Media, Self-directed Learning, Health Literacy.
\end{abstract}

\begin{abstract}
Öz
Çocuklarda Sosyal Medya Kullanım Amaçları ve Teknoloji ile Kendi Kendine Öğrenmenin Sağlık Okuryazarlığı Üzerine Etkisi

Giriş: Sağlık okuryazarlığı; yeni bilgiler elde etmeye, daha pozitif tutumlara, daha fazla öz yetkinliğe, olumlu sağlık davranışlarına ve daha iyi sağlık sonuçlarına ulaşmak için bir yol olarak tanımlanmaktadır. Yapılan çalışmalar sosyal medya kullanım amacı ve teknoloji ile kendi kendine öğrenme çocukların sağlık okur-yazarlığını etkilediğini vurgulamaktadır. Amaç: Bu çalışma öğrencilerin sosyal medya kullanım amaçları ve teknoloji ile kendi kendine öğrenmelerinin sağlık okuryazarlığına etkisini değerlendirmek amacıyla yapılmıştır. Yöntem: Çalışma Türkiye'nin Ege bölgesinde yer alan iki ayrı ortaokulda 507 öğrenci ile yapılmıştır. Çalışmada veri toplama aracı olarak "Tanımlayıcı Bilgi Formu", "Sosyal Medya Kullanım Amaçları Ölçeği”, "Çocuklar İçin Teknolojiyle Kendi Kendine Öğrenme Ölçeği” ve "Okul Çağındaki Çocuklar İçin Sağlık Okuryazarlığı Ölçeği” kullanılmıştır. Bulgular: Regresyon analizi sonucunda, çocukların sosyal medya kullanım amacı toplam puan ortalamaları ve sağlı okur-yazarlığı arasında pozitif orta derecede anlamlı bir ilişki $(\beta=.60, p<.001)$, teknoloji ile kendi kendine öğrenme ve sağlık okur yazarlı̆̆ arasında pozitif orta derecede anlamlı bir korelasyon bulunmuştur $(\beta=.58, \mathrm{p}<.001)$. Öğrencilerin sağlık okur-yazarlı̆̆ını sırasıyla en çok sosyal medya kullanım amaçları ve teknoloji ile kendi kendine öğrenme toplam puan ortalamalarının etkilediği saptanmıştır. Modelin genelinde sağlık okuryazarlığını etkileyen faktörlerin \%46'sının $(\mathrm{F}=92.915, \mathrm{p}<.001)$ sosyal medya kullanım amaçları ve teknoloji ile kendi kendine öğrenme ile açıklandığı bulunmuştur. Sonuç: Çocukların sağlık okuryazarlığı ile sosyal medya kullanım amaçları ve teknoloji ile kendi kendine öğrenme arasında pozitif yönde anlamlı bir ilişki olduğu belirlenmiştir.

Anahtar Sözcükler: Sosyal Medya, Kendi Kendine Öğrenme, Sağlık Okuryazarlığı.
\end{abstract}

Geliş Tarihi / Received: 16.09.2020 Kabul Tarihi / Accepted: 16.09.2021

Correspondence Author: Phd, Assoc Prof, Dokuz Eylul University Faculty of Nursing, Pediatric Nursing Department, Izmir, Turkey, 35340 Phone: +905433852905 Email: dijle.ozer@deu.edu.tr

Cite This Article: Ayar D, Bektaş İ, Akdeniz Kudubes A, Bektaş M. Social Media Use Purposes of Children and The Impact of Their Self-Directed Learning with Technology on Health Literacy Dokuz Eylül Üniversitesi Hemşirelik Fakültesi Elektronik Dergisi. 2021; 14(4.): $387-394$ 
$\mathbf{H}$

ealth literacy is described as individuals' wishes to have access to health-related information sources, to adequately perceive and understand health-related information and messages in order to make decisions on issues about health services throughout their lives. Health literacy which helps them to protect, maintain and improve their health and increase the quality of their life (1). Health literacy is about much more than simply having the basic educational skills for applying language, literacy and numeracy skills to process information on health issues. It is also about having knowledge, confidence and skills to seek out and interpret information; for instance, to know what to look for when health-related claims are made about specific products and activities, as well as being better able to understand the concepts of risk and benefit associated with different lifestyle choices or different health care treatment options (2). Health literacy which is accepted as a crucial step in planning health development activities is important in health-related behavioral change and skill development especially in childhood $(1,3)$. Besides, in preventing risky health behaviors that may occur in future, it has been determined as a significant concept that needs to be considered in childhood to reinforce healthy behaviors (2).

Studies have revealed that children/adolescents with low health literacy level have difficulty in dealing with chronic diseases (4), behave in risky way (smoking and aggression) and have more tendencies to obesity (5). In the study conducted by Hanson and Gluckman (2011) (6), it was indicated that evaluating health literacy since childhood and such attempts in accordance with its maintenance are significant factors in decreasing contagious diseases. It is crucial to examine the factors affecting health literacy which is accepted as an important concept in both protecting and improving child health, as well as forming healthy population in adulthood.

Social media today is progressing swiftly through various applications and becoming very popular for people in their access to health-related information (7). Especially, children are highly interested in social media applications and websites (Facebook, Twitter, LinkedIn, Myspace); and they count on those sites to play computer games, communicate and reach information (8,9). Fairbrother, Curtis \& Goyder (2016) (10) determined in their study carried on health information access and health literacy of 53 children aged 9-to-10 that children could reach the information for healthy foods through various information tools (social media sites, professionals, advertisements). Besides, American Pediatric Academy (2012) (11) indicated that social media sites disseminate various health-related information and that health literacy level is important for children to understand this information properly. Various other studies have demonstrated that social media sites are used and preferred by people in spreading health-related information. It has also been emphasized that they are of vital importance on coming up with a decision on issues about health (12). Studies on social media have revealed that it has positive effect on individuals' getting, forming and sharing information, and on their communication skills (13). It has been well established that social media is a powerful instrument for health literacy (14) and that there is a strong connection between social media and health literacy in health development process. Furthermore, social media has been determined as a powerful instrument used in disseminating true health-related information especially in developing countries (15).

Another factor affecting health literacy of children is the level of self-directed learning with technology. Selfdirected learning is a learning approach that individuals determine their priorities and choose them among various accessible sources. Self-directed learning enables students to take their responsibility of the process, to find proper sources for learning targets and decide learning and evaluating methods. Studies have revealed that technology influences self-directed learning and is frequently used in pursuit of information particularly by children (16). Especially self-directed learning with technology enables students to take their own responsibilities in their learning process and also to develop their critical thinking skills (17).

Health literacy is described as a means to obtain new information and reach more positive attitudes, more competence, positive health behaviors and better health outcomes (18). Schools are the areas where children between the ages of 5 to 17 realize their social and psychological development and spend about six hours a day. Schools play an important role in promoting the health and safety of children and adolescents by helping them to establish lifelong health patterns. Schools have a significant potential to promote health related theoretical and practical knowledge and other components of health literacy $(19,20)$. Also, schools are important settings for health promotion through the creation of health and well-being in childhood and adolescence (21). Healthy schools promote health education that instills lifelong healthy habits and health literacy (22). Busch, de Leeuw, de Harder, \& Schrijvers (2013) (23) reviewed the literature on school-based interventions to change adolescents' health-related behaviors. In their study, Velardo \& Drummond (2015) (24) found that teachers are guiding in improving health literacy in the school environment and in reaching reliable sources of information for students. In the same study, students reported that using technology to teach them the right direction to reach the correct source of information.

It has been emphasized in literature that there is not sufficient number of studies regarding health literacy of children as yet. Moreover, it has been revealed when the related studies are investigated that mostly the effect of parental health literacy on child and child care is examined in most of these studies (25). Children's purpose of social media uses and their self-directed learning with technology have been thought to affect health literacy which has an important influence on child development and child health. When the related literature is scrutinized, no studies can be seen regarding the influence of both children's purpose of use for social media and their self-directed learning with technology on health literacy.

Aim

The purpose of this study is to examine the effect of social media use purposes of the children and their self-directed learning with technology on health literacy. 
Type of the Research:

\section{Methods}

This study was conducted in descriptive, cross-sectional, and correlational study methods with the aim of evaluating the effect of children's purpose of use of social media use purposes and their self-directed learning with technology on health literacy. Place and Time of the Research

The study was conducted with a total of 507 students from two secondary schools located in Turkey's Aegean region. It was conducted between March and June 2019.

\section{Research Universe/Sample}

In $G^{*}$ Power 3.0 Statistical Program, accepting Type 1 error rate (0.01) and Type 2 error rate (0.05) (99\% power), the required sampling size was determined as 132 students. For a better understanding of relation between variances, a sampling group of 507 students was formed consisting of those from fifth, sixth, seventh and eighth-graders with parental consent accepting to voluntarily participate in the study and fulfilling the scales. Inclusion criteria in the sample were as follows; a) children with parental consent who volunteered to participate in the study, and the children enrolled into the study should be social media users, while the exclusion criteria in the study were; a) children with specific learning disability, b) children demanding to withdraw in any phases of the study, c) the children without parental consent.

The data were collected in the classrooms after the researchers informed the students about the purpose of the research and obtained signed parental consent to conduct the study. The data collection tools were applied by the researchers accordingly.

\section{Measurement Instrument}

In the study, "Descriptive Information Form", "Social Media Purpose Use Scale", "Self-Directed Learning with Technology Scale" and "Health Literacy Scale for School-Aged Children" were used as data collection tools.

Descriptive Information Form

Descriptive information form was created by the researchers reviewing the literature, which consisted of questions with regard to children's sociodemographic data, age, sex, grade; frequency of internet use and intention and frequency of social media use.

Social Media Use Purposes Scale

The social media use purpose scale was developed by Eren Şisman (2014) (8) in an attempt to determine children's and adolescents' intention while using social media. The scale aims to measure middle and high school students' purpose of social media use in two dimensions as interpersonal communication and lesson preparation. The scale which is fivepoint Likert type (1=Never, 5=Always) consists of 12 items (8). Factor loading value of the first sub-dimension of the scale (interaction between individuals) is .63 to .80. Factor loading value of the second sub-dimension of the scale (preparation for the course) is .50 to .62. KMO value of the scale was calculated as .89. Cronbach Alpha coefficient of the scale was calculated as .89 , the first and the second factor's reliability coefficient as .88 and .80 respectively. The scale was determined as a valid and reliable measurement tool in identifying the intention of social media use in terms of children and adolescents in Turkish sampling group (8).

Self-Directed Learning with Technology Scale

Self-Directed Learning with Technology Scale developed by Teo et al. (2010) (16) was approved by Demir \& Yurdagul (2013) (26) in terms of its reliability and validity. It determines the level of children's self-directed learning with technology. The scale consists of six items such as" I can ask questions to my teacher about lessons over internet in outof-school time", "I use computer to share my thoughts about my homework" (e-mail, YouTube and Facebook etc.), "I use computer to get more information that may help me learn a lecture", "I use computer to have an idea from different websites and people so as to learn a lecture more". KMO value for Turkish scale was determined as .794 and Bartlett test as $.000(\chi 2=1098.350)$. As a result of Explanatory Factor Analysis, it was detected that the scale explains 59,316\% of total variance. Cronbach Alpha coefficient is .73. Item-total correlation was determined as .64 to .85. Consequently, self-directed learning with technology scale for children was confirmed as a valid and reliable measurement tool (26).

Health Literacy Scale for School-Aged Children

The scale which was developed by Paakkari, Torppa, Kannas, \& Paakkari (2016) (27) evaluates health literacy of school children. It consists of 10 items. These items have four-point Likert type response options (Strongly not true=1, Mostly not true=2, Slightly true=3, Strongly true=4). Adding up the items, the total score varies between 10 to 40 points; in scale point 10-25 points stands for low, 26-35 for middle and 36-40 for high health literacy (27). Validity and reliability of the scale were evaluated by Haney (2018) (28). Fit Indices of the scale are as follows: (root mean square error of approximation $(R M S E A)=.035$, the goodness-of-fit index $(G F I)=.99$, comparative fit index $(C F I)=.99$, normal fit index $(N F I)=.98$, non-normal fit index $(\mathrm{NNFI})=.98$, adjusted goodness-of-fit index $(\mathrm{AGFI})=.97, \chi 2=38.86, \mathrm{df}=23$, $\chi 2 / \mathrm{df}=1.68, \mathrm{p}=.05)$. Total Cronbach Alpha coefficient was calculated as .77, item-total correlation as .30 - .60. Itemtotal correlations were between .49 and .61 and were statistically significant to be a valid and reliable scale that could be used on Turkish children (28).

\section{Variables of the Study}

Independent Variables: Independent variables of the study; the mean scores obtained from the social media use purposes and self-directed learning with technology. Dependent Variables: The dependent variables of the study; the mean scores obtained from the health literacy.

\section{Data Analysis}

The data were analyzed using SPSS version 24.0 (IBM Corp, 2016). Descriptive analyses were conducted using percentages, means, and standard deviation. The relationships among health literacy, Social Media Use Purposes and 
Self-directed learning with technology were assessed using bivariate correlation analyses (Pearson's r). Pearson correlation coefficients is a bivariate statistic that measures how strongly two variables are related to one another. Effects of students' Social Media Use Purposes and Self-directed Learning with technology level on their health literacy level were assessed using multiple linear regression analyses and multicollinearity testing was performed for regression analysis. Predictors added to the model by variance inflation factor coefficients were less than 10 and the tolerance coefficients were greater than .20. Multiple linear regression is to seek for the linear relationship between a dependent variable and several independent variables. The threshold for significance was .05 .

\section{Ethical considerations}

Research and publication ethics were followed in the article. Prior to the research, permits were obtained from the owners of the scales used in the research via email. The written consent of University Non-Invasive Research Ethics Board was obtained with decision number (4321-GOA, 2018/26-15), and written institutional permit from the Provincial Directorate of National Education, and written consents of the adolescents and their parents were obtained. Before the study, parents were informed about the study content in a meeting at the school. Informative forms about the aim of the study and content were mailed to parents who did not attend the meeting. Only the students whose parents gave written consent were included in the study.

\section{Results}

A total 507 (mean age $=12.43$ years, $55.9 \%$ ) of the students participating in the study was composed of girls, $18.3 \%$ were in the fifth grade, $22.3 \%$ were in the sixth grade, $29.6 \%$ were in the seventh grade and $29.8 \%$ were in the eighth grade. The total of students $8.7 \%$ were 10 years, $19.7 \%$ were 11 years, $25.2 \%$ were 12 years, $30 \%$ were 13 years and $16.4 \%$ were 14 years.

It was reported that $17.6 \%$ of the students started using the internet at the age of 5, while $37.9 \%$ stated that they used the internet 1-2 hours per day, 20.9\% used the internet four hours per day and $55.6 \%$ used the internet every day. When the social network preferences of the students were studied, it was found that most of them used Facebook, YouTube and Instagram. The daily frequency of social media use was found as 39.3\% for YouTube, 29.9\% for Instagram. When the health literacy levels of the students were studied, it was reported that $18.7 \%$ of the students had low levels of health literacy, whereas $27.2 \%$ had high levels of health literacy.

When the correlation between health literacy and the purpose of social media use and self-directed learning with technology was studied in the students, it was found that there was a positive strong correlation $(r=.60, p<.001)$ between health literacy and the purpose of social media use; there was a positive moderate significant correlation $(r$ $=.58, p<.001$ ) between health literacy and self-directed learning with technology, while there was a positive moderate significant correlation $(r=.51, p<.001)$ between the purpose of social media use and self-directed learning with technology (Table 1).

Table 1. The Correlation between Social Media Use Purposes and Self-Directed Learning with Technology and Health Literacy

\begin{tabular}{lccc}
\hline Health literacy & 1 & 2 & 3 \\
$\begin{array}{l}\text { 2. Social Media Use } \\
\text { Purposes Self-Directed }\end{array}$ & $1.00^{*}$ & $1.0^{*}$ & \\
$\begin{array}{l}\text { 3. } \quad .60^{*} \\
\text { Learning with }\end{array}$ & $.58^{*}$ & $.51^{*}$ & $1.0^{*}$ \\
Technology & & & \\
$* p<.001$ & & &
\end{tabular}

The multiple regression analysis showed that there was a positive strong significant correlation between health literacy and the purpose of social media use in Model $1(\beta=.60, p<.001), 36 \%$ of the factors affecting health literacy $(F=289.205, p<.001)$ were accounted by the mean total score of the purpose of social media use. In Model 2, there was a positive moderate significant correlation between the mean scores of health literacy and self-directed learning with technology $(\beta=.58, p<.001), 33 \%$ of the factors affecting health literacy in the students $(F=250.995, p=.001)$ were accounted by the mean total score of self-directed learning with technology. When the correlation between health literacy and two other variables in Model 3, there was a positive moderate significant correlation $(\beta=.42, p<.001)$ between the mean total scores of the purpose of social media use and health literacy and there was a positive moderate significant correlation between self-directed learning with technology $(\beta=.36, p<.001)$. The health literacy of the students was mostly affected from the mean total scores of the purpose of social media use and the self-directed learning with technology, respectively. It was found that $46 \%(F=215.872, p<.001)$ of the factors affecting the health literacy in the overall model could be accounted by the purpose of social media use and self-directed learning with technology (Table 2). 
Table 2. Multiple Linear Regression Analysis of the Factors That Affect Health Literacy

\begin{tabular}{lccc}
\hline & Model 1 & Model 2 & Model 3 \\
\hline $\begin{array}{l}\text { Social media use } \\
\text { purposes }\end{array}$ & $\beta$ & $\beta$ & $\beta$ \\
\hline $\begin{array}{l}\text { Self-Directed Learning } \\
\text { with Technology }\end{array}$ & $.60^{*}$ & & $.42^{*}$ \\
\hline $\mathbf{R}^{2}$ & & $.58^{*}$ & $.36^{*}$ \\
\hline $\mathbf{F}$ & .36 & .33 & .46 \\
\hline $\mathbf{p}$ & 289.205 & 250.995 & 215.872 \\
\hline
\end{tabular}

Note: $p<.001^{*}$

\section{Discussion}

The results of this study demonstrate the effect of the purpose of social media use purposes and the self-directed learning with technology on the health literacy of the students. In this study, three models were created by considering the correlations between the variables. In the students, Model 1 evaluated the correlation between the mean total scores of health literacy and the purpose of social media use; Model 2 evaluated the correlation between the mean total scores of health literacy and the self-directed learning with technology; Model 3 evaluated the correlation between the mean total scores of health literacy and all other variables.

Model 1 shows that the students with higher mean scores of purposes of social media use had also higher mean scores of health literacy. In this study, the mean scores of the purpose of social media use had an important place among the factors affecting health literacy (36\%, Table 2). Online health information has become increasingly popular because of the rapid increase in Internet use and ease of access to Internet based information (29). Social media has emerged as a potentially powerful medium for communication with youths around their health choices. Youths have access to more health information than in the past and possess the capacity to take an active role in tasks such as self-monitoring their health (30). In recent years, the use of social media sites such as Facebook, YouTube and Twitter have been increasing. In particular, social media is recommended to increase the access to science-based health services and to share information. For users, social media use is preferred because they reach the information whenever and wherever they want (31). American Academy of Pediatrics (2012) (11) stated that social media sites spread various health related information and that the level of health literacy is important for children to understand this information correctly. The studies show that social media sites are frequently used and preferred to share health-related information $(12,13)$. It is especially stated that it is very effective in making decisions about health (12). Social media can potentially improve adolescents' capacity to obtain, and process and understand health information and services needed to make appropriate health decisions (32). It is known that social media is a very powerful tool for health literacy and there is a strong correlation between social media and health literacy in terms of health development (14). Chen et al. (2018) (33) stated in their study people with lower health literacy were more likely to use and trust health information from sources that might be lower quality (i.e., social media, blogs). Social media is a very powerful tool used to spread the correct health information especially in the developing countries. When the correlation between the purpose of social media use and health literacy is evaluated; Rosenbaum et al (2018) (34) stated in their study that there is a positive correlation between the use of health-related social media sites and health literacy, and the purpose of social media use is an important variable in determining healthy and unhealthy behaviors. Besides, the studies reported that the use of social media also provides effective learning of individuals (35). Literature support the Model 1 showing that the students with higher mean scores of purposes of social media use had also higher mean scores of health literacy.

Model 2 showed that the students with higher mean scores of self-directed learning with technology had also higher mean scores of health literacy. In this study, the mean scores of the self-directed learning with technology had an important place among the factors affecting health literacy (33\%, Table 2). Self-directed learning is important as one pursues lifelong learning when engaging in non-routine analytic tasks and complex problem solving. Studies on Selfdirected learning have also reported the close relationship between self-directed learning and the use of technologies in learning. Vonderwell and Turner (2005) (36) indicated that an online learning environment provides more control of the instruction to the learners and thereby could enhance aspects of self-directed learning, in are as such as students taking responsibility and initiative towards their learning. Technology may have direct impact on self-directed learning because it has greatly facilitated access both to information resources and toonline expertise. For the learners, being able to access a wide and unlimited range of information to serve their learning needs and interestsare important to selfdirected learning (37).

In particular, the concept of health literacy should be considered as a broad concept that includes self-access to information for children with the use of technology, and the ability of children to have a self-access to health information and learning skills should be emphasized (38). Self-directed learning ability of the students occupies an important part in terms of life-long learning period (39). Today, the students use technological applications as a learning tool for both professional development and individual needs, and use of technology also supports learning (40). Literature supports the Model 2 showing that the students with higher mean scores of self-directed learning with technology had also higher mean scores of health literacy.

Model 3 showed that the students with higher mean scores of purpose of social media use and self-directed 
learning with technology had also higher mean scores of health literacy. In this study, the mean scores of purpose of social media use and self-directed learning with technology had an important place among the factors affecting health literacy (46\%, Table 2). Self-learning is a facilitating factor for students to learn the information they need. "Focuses on students' ability to self-assess their own learning needs in order to carry out activities to inquire and find out about the things they want to know". Besides, self-directed learning ability is also important for life-long learning period (41). It is emphasized in recent years that the use of technology supports the self-learning ability of the students (42). Health literacy is defined as the capacity to make health-related optimal decisions, self-search and learning capacity of health information, and it is reported that there is a direct correlation between health literacy and self-learning capacity (43). It is considered that as an important concept, self-learning has positive effects on health literacy.

\section{Limitation}

Collection of data from only two secondary school is the limitation of this study.

\section{Use of Results in Practice}

It is important to develop health literacy skills early in life. In literature especially, effective health literacy interventions can positively influence education and academic performance, which can have long-term benefits across the life course. One of the key traits of so called $21^{\text {st }}$ century learners is self-directed learning, where students manage the learning process on their own, all from setting their own learning goals to the final evaluation of their own learning. Self-directed learning is a desirable skill leading to more learning and more time spent on learning. It is recommended that technologies can be used anytime and anywhere, they need to be integrated into learning systems in an unobtrusive manner, engaging and stimulating students on repeated use. Health literacy levels of children should be evaluated, and the affecting factors should be examined comprehensively, besides, the interventional studies should be conducted to improve health literacy. Health literacy should be part of any effective framework for improving the delivery of quality child health and school services. In addition, health literacy is essential tools that can help parents help their children meet the objectives supporting school readiness. Literacy programs are also more likely to be implemented when embedded into routine educational practices. To support this, it may be feasible in some settings to make the teaching of health literacy in schools mandatory as part of the education curriculum. School inspectorate systems may subsequently have a role to play in assessing the quality and fidelity of programs. The implementation of interventional programs is recommended, in which multi-component interventions would be applied to increase health literacy level of adolescents. It is recommended that school nurses help adolescents recognize the relationships between social media, self-directed learning, and health literacy in their intervention programs.

\section{Acknowledgement}

Authorship contribution statement; DA: Conceptualization, Data curation, Formal analysis, Investigation, Methodology, Resources, Software, Supervision, Writing - original draft, Writing - review \& editing. İ: Data curation, Formal analysis, Investigation, Methodology, Resources, Software, Supervision, Writing - original draft, Writing - review \& editing. AAK: Data curation, Formal analysis, Investigation, Methodology, Resources, Software, Supervision, Writing - original draft, Writing - review \& editing. MB: Data curation, Formal analysis, Investigation, Methodology, Resources, Software, Supervision, Writing - original draft, Writing - review \& editing. We thank all students who participated in the study. The authors stated no apparent conflicts of interest about this article's work, authorship and/or publishing. The authors did not get financial support for this article's analysis, authorship and/or printing. 


\section{References}

1. WHO Regional Office for Europe. (2013). Health literacy: the solid facts. Copenhagen: WHO Regional Office for Europe. URL: http://www.euro.who.int/_data/assets/pdf_file/0008/190655/e96854.pdf 16 April 2020

2. McDaid D. (2016). Investing in health literacy. What do we know about the co-benefits to the education sector of actions targeted at children and young people? URL: http://www.euro.who.int/_data/assets/pdf_file/0006/315852/Policy-Brief-19-Investing-health-literacy.pdf 16 April 2020

3. Bröder J, Okan O, Bauer U, Bruland D, Schlupp S, Bollweg TM, et al. Health literacy in childhood and youth: a systematic review of definitions and models. BMC Public Health 2017; 17(1): 361.

4. Perry EL, Carter PA, Becker HA, Garcia AA, Mackert M, Johnson KE. Health literacy in adolescents with sickle cell disease. J Pediatr Nurs 2017; 36: 191-196.

5. Sharif I, Blank AE. Relationship between child health literacy and body mass index in overweight children. Patient Educ Couns 2010; 79(1): 43-48.

6. Hanson M, Gluckman P. Developmental origins of noncommunicable disease: population and public health implications. Am J Clin Nutr 2011; 94(6): 1754S-1758.

7. Levin-Zamir D, Bertschi I. Media health literacy, e-health literacy, and the role of the social environment in context. Int J Environ Res Public Health 2018 3; 15(8): 1643.

8. Eren Şişman E. Developing social media use purposes scale and examining based on some personal variables. H. U. Journal of Education 2014; 29(4): 230-243.

9. Wang Q, Chen W, Liang Y. (2019). The effects of social media on college students. Research \& Analysis. URL: http://scholarsarchive.jwu.edu/mba_student/5. 11 April 2020

10. Fairbrother H, Curtis P, Goyder E. Making health information meaningful: Children's health literacy practices. SSM Popul Health 2016; 16(2): 476-484.

11. American Academy of Pediatrics. (2012). Health Literacy and Pediatrics. URL: https://www.aap.org/enus/professional-resources/Research/research-resources/Pages/Health-Literacy-and-Pediatrics.aspx 11 April 2020

12. Fernández-Luque L, Bau T. Health and social media: perfect storm of information. Healthc Inform Res. 2015; 21(2): 67-73.

13. Sistek-Chandler C. Connecting the digital dots with social media and Web 2.0 technologies. Journal of Research in Innovative Teaching. 2012; 5(1): 78-87.

14. Osborne H. Social media and health literacy. AMWA Journal. 2017; 32(3): 124-125.

15. Lau AY, Siek KA, Fernandez-Luque L, Tange H, Chhanabhai P, Li SY, et al. The role of social media for patients and consumer healt. Yearb Med Inform. 2011; 6(1): 131-138.

16. Teo T, Tan SC, Lee CB, Chai CS, Koh JHL. The self-directed learning with technology scale (SDLTS) for young students: An initial development and validation. Computers \& Education. 2010; 55(4): 1764-1771.

17. Song L, Hill JR. A conceptual model for understanding self-directed learning in online environments. Journal of Interactive Online Learning, 2007; 6(1): 27-41.

18. Aslantekin F, Yumrutaş M. Health literacy and measurment. TAF Prev Med Bull, 2014; 13(4): 327-334.

19. Paakkari L, Paakkari O. Health literacy as a learning outcome in schools. Health Education, 2012; 112(2): 13352.

20. Kickbusch I, Pelikan JM, Apfel F, Tsouros A. (2013). Health Literacy: the solid facts. Copenhagen: World Health Organisation.

21. Blom-Hoffman J, Wilcox KR, Dunn L, Leff SS, Power TJ. Family involvement in school-based health promotion: bringing nutrition information home. School Psych Rev 2008; 37(4): 567-577.

22. Centers for Disease Control and Prevention. (2019). Social Media at CDC. URL: https://www.cdc.gov/socialmedia/. 16 September 2020

23. Busch V, de Leeuw JR, de Harder A, Schrijvers AJ. Changing multiple adolescent health behaviors through school-based interventions: a review of the literature. J Sch Health 2013; 83(7): 514-23.

24. Velardo, S., \& Drummond, M. (2015). 'Teacher health literacy: The importance of multiple healthy role models within the school environment'. Conference: Values into Action- A Brighter Future: Edited Proceedings of the 29th ACHPER International Conference. Adelaide, SA: ACHPER SA. 29th ACHPER International Conference. Adelaide. Apr 2015At: Adelaide

25. Sanders LM, Federico S, Klass P, Abrams MA, Dreyer B. Literacy and child health: A systematic review. Arch Pediatr Adolesc Med 2009; 163(2): 131-140.

26. Demir O, Yurdugül H. Self-directed learning with technology scale for young students: A validation study. Einternational Journal of Educational Research 2013; 4(3): 58-73.

27. Paakkari O, Torppa M, Kannas L, Paakkari L. Subjective health literacy: Development of a brief instrument for school-aged children. Scandinavian Journal of Public Health 2016; 44: 751-757.

28. Haney MO. Psychometric testing of the Turkish version of the health literacy for school-aged children. Journal of Child Health Care 2018; 22(1): 97-107.

29. Jacobs W, Amuta AO, Jeon KC. Health information seeking in the digital age: An analysis of health information seeking behavior among US adults. Cogent Social Sciences 2017; 3: 1302785

30. Boonwattanopas N. Use of online social media and ehealth literacy of urban youth in phuket province, Thailand. Eau Heritage Journal Science and Technology 2016; 10(1): 48-62. 
31. Centers for Disease Control and Prevention. (2013). Social Media at CDC. URL: https://www.cdc.gov/socialmedia/ 11 April 2020

32. Boulos K. On Social media in health literacy. Webmed Central Health Informatics 2012; 3(1): WMC002936

33. Chen X, Hay JL, Waters EA, Kiviniemi MT, Biddle C, Schofield E, et al. Health literacy and use and trust in health information. Journal of Health Communication 2018; 23:8, 724-734.

34. Rosenbaum JE, Johnson BK, Deane AE. Health literacy and digital media use: assessing the health literacy skills instrument short form and its correlates among African American college students. Digital health. 2018; 14: 4,2055207618770765.

35. Johnson KA. The effect of Twitter posts on students' perceptions of instructor credibility. Learning, Media and Technology. 2011; 36(1): 21-38.

36. Vonderwell S, Turner S. Active learning and preservice teachers' experiences in an online course: a case study. Journal of Technology and Teacher Education, 2005; 13(1), 65-84.

37. Timothy T, Cheea TS, Beng LC, Sing CC, Ling KJH, Li CW, et al. The self-directed learning with technology scale (SDLTS) for young students: An initial development and validation. Computers \& Education, 2010; 55(4): 1764-1771.

38. Abrams MA, Klass P, Dreyer BP. Health literacy and children: introduction. Pediatrics. 2009; 124(3): $262-4$.

39. Ananiadou K, Claro M. (2009). 21 st century skills and competences for new millennium learners in oecd countries, OECD Education Working Papers (Report no:41). France, Paris: OECD Publishing. http://dx.doi.org/10.1787/218525261154

40. Bonk CJ, Lee MM, Kou XX, Shuya Xu, Feng-Ru S. Understanding the self-directed online learning preferences, goals, achievements, and challenges of mit open course ware subscribers. Educational Technology \& Society 2015; 18(2): 349-365.

41. Voogt J, Roblin NP. A comparative analysis of international frameworks for 21 st century competences: Implications for national curriculum policies. Journal of Curriculum Studies 2012; 44: 299-321.

42. Collins A, Halverson R. The second educational revolution: Rethinking education in the age of technology. Journal of Computer Assisted Learning 2010; 26:18-27.

43. Mancuso JM. Health literacy: a concept/dimensional analysis. Nurs Health Sci 2008; 10(3): 248-55. 